Türkiye Jeoloji Bülteni
Geological Bulletin of Turkey
$62(2019) 99-112$
doi: $10.25288 /$ tj b.519506

\title{
Açık Maden İşletmelerinde İnsansız Hava Aracı (İHA) Uygulamaları
}

Applications of Unmanned Aerial Vehicle (UAV) in open-pit mines

\section{Yavuz Gül $\mathbb{D}$}

\author{
Sivas Cumhuriyet Üniversitesi, Maden Mühendisliği Bölümü, 58140 Sivas
}

Geliş/Received : 28.11.2018 • Düzeltilmiş Metin Geliş/Revised Manuscript Received : 22.01.2019 • Kabul/Accepted : 25.01.2019 • Bask1/Printed : 05.02 .2019 Araştırma Makalesi/Research Article Türkiye Jeol. Bül. / Geol. Bull. Turkey

Öz: Son yıllarda açık maden işletme sahalarında haritacılık işlemleri, gerek maliyet gerek zaman gerekse iş güvenliği açısından avantajlı olan İnsansız Hava Araçları (IHHA) kullanılarak gerçekleştirilmektedir. İHA ile zorlu arazi şartlarında kolay, hızlı, yüksek hassasiyetli ve ekonomik ölçümler yapılabilmektedir. Bu çalışmada, açık işletmelerde İHA tabanlı haritalama uygulamalarının avantajları açıklanmıştır. Bu kapsamda, İHA fotogrametrisiyle üretilen ortofoto haritalar, Sayısal Yükseklik Modelleri (SYM), dekapaj ve üretim miktarı hesapları, stok ve döküm hacmi tespiti ve deformasyon ölçüm çalışmaları sunulmuştur.

Anahtar Kelimeler: 3D modelleme, açık maden işletmesi, fotogrametri, İHA

\begin{abstract}
In recent years, mapping operations in open-pit mines are made by using Unmanned Aerial Vehicles (UAV) having the advantages of cost, time and occupational safety. Using UAVs, easy, fast, high sensitive and economic measurements can be done in difficult field conditions. The advantages of UAV based mapping applications in open-pit mines are explained in this study. Within this scope, orthophoto maps produced by UAV, digital elevation models (DEM), amount of stripping and production calculations, stock and dumping volume determinations and deformation measurement studies are presented.
\end{abstract}

Keywords: $3 D$ modelling, open-pit mine, photogrammetry, UAV

\section{GíRiş}

İHA platformları, günümüzde fotogrametrik veri üretiminde farklı disiplinler ve farklı uygulama alanları için denetim, gözetim ve analiz yapmaya olanak veren önemli bir veri kaynağıdır. İHA, güncel veriye hızlı ve ekonomik ulaşma yönünden kolaylıkla kullanılabildiğinden harita, maden, jeoloji, inşaat ve çevre mühendisliği gibi yer bilimlerini ilgilendiren disiplinlere önemli katkılar sunmaktadır. Gelişen fotogrametrik sensör, platform ve uzaktan algılama teknolojileri sayesinde İHA, klasik hava fotogrametrisine göre yüksek mekansal ve zamansal çözünürlük olanaklarını sağladığından gittikçe yaygınlaşan bir platformdur. İHA'ların fotogrametrik veri üretimi amacıyla kullanılması ile hızlı çözümleme ve düşük maliyet sağlanmaktadır.

1970'lerde askeri amaçlarla kullanılmaya başlayan İHA'ların $2000 \quad$ yılı sonrası silahlandırılabilmesi ile dünya genelinde İHA'ların yaygın kullanımında önemli gelişmelerin olduğu görülmektedir. Farkl1 platformlardan uzaktan yönlendirilen bu araçlar, artık binlerce mil uzaktan uydu haberleşmesi kanalıyla kontrol edilebilmektedir (Akyürek vd., 2012). İHA'lar ile askeri alanlarda büyük başarı yakalanmasının ardından, sivil havacilıkta kullanılabilirliği üzerine çalışmalar başlamıştır. Düşük maliyeti ve

\footnotetext{
*Yazlşma/Correspondence:ygul@cumhuriyet.edu.tr
}

(C) 2019 JMO Her hakkı saklıdır/All rights reserved http://tjb.jmo.org.tr http://dergipark.gov.tr/tjb 
insansız uçma özelliği ile çalışma alanlarının zor olduğu bölgelerde sivil kullanıcılar için de çok avantajlı çözümler sunmaktadır. Bununla birlikte İHA'lar özellikle petrol hatları, demiryolu hatları, yüksek yapıların kontrolünde, zirai ilaçlama, ürün rekoltesinin tespiti, deprem sonras1 görüntüleme ve benzeri birçok alanda kullanılmaktadır (K1lınçoğlu, 2016).

Mevcut kullanımda bir kişi tarafından taşınacak kadar hafif ve maliyet/fayda oranı oldukça yüksek olan İHA'lar bir kamera, GNSS (Global Navigation Satellite System), IMU (Inertial Measurement Unit), radyo bağlantısı ve küçük bir bilgisayar işlemcisi ile donatılabilmektedir. Bu ufak İHA'ların çoğunun fiyat1 5000 - 60000 USD (Amerikan Doları) arasındadır. Ağırlıkları genellikle 0,5 ila $3,5 \mathrm{~kg}$ arasındadır. Bu cihazlar haritacılık, madencilik, tarım, çevre izleme ve yönetimi, şehircilik, koruma vb. çeşitli uygulamalarda kullanılmaktadır (Barry ve Coakley, 2013).

İHA'lar ve dijital fotogrametrik kameraların son on yıldaki gelişimi ve yaygın kullanımı ile fotogrametrinin önemi artmış ve harita üretimi için daha uygun bir çözüm haline gelmiştir. GNSS ölçü yöntemleri ile oluşturulan az miktarda ki yer kontrol noktaları ile doğrudan bağlantı kurarak veya İHA üzerinde bulunan RTK (Real Time Kinematic) GNSS sistemleri kullanılarak, yoğun yer örneklem noktaları kolaylıkla elde edilebilmektedir. Elde edilen yoğun nokta bulutları, eskiden yalnızca LIDAR (Laser Imaging Detection and Ranging) ile elde edilebilmekteyken günümüzde İHA'ların kullanımı, yüksek doğrulukta ortofoto haritalar ve sayısal yüzey modeli yani DSM (Digital Surface Model) oluşturmaya imkân vermektedir (Gonçalves ve Henriques, 2015; Peterman, 2015; Bui vd., 2017).

İHA'ların fotogrametrik potansiyeli yakın geçmişte çeşitli çalışmalarda değerlendirilmiştir. Bugünkü durumda birçok uygulamada da kullanılmaktadır. $\mathrm{Bu}$ çalışmaların yanı sıra elde edilen ortofoto haritaların ve SYM'lerin doğruluğunu artırmaya yönelik araştırmalarda sürmektedir (Harwin ve Lucieer, 2012; Barry ve Coakley, 2013; Udin ve Ahmad, 2014; Cryderman vd., 2014; Babinec ve Apeltauer, 2016; Kılınçoğlu, 2016; Popescu vd., 2016; Kršák vd., 2016; Ulusoy vd., 2017; Yusoff vd., 2017).

İHA fotogrametrisindeki bu gelişmeler doğrultusunda, açık maden işletmelerindeki halihazır harita üretimi, üç boyutlu (3D) modelleme, üretim ve dekapaj miktarının belirlenmesi, stok ve döküm sahası kübaj hesapları, kayaç tespiti, jeolojik haritalama, kazı planlaması ve hiperspektral kameraların takılması ile beraber alterasyon ve mineral tespiti, dik ve erişilemeyen noktaların haritalanması gibi çalışmalarda da yöntemden faydalanılmaktadır (Câmara vd., 2013; Hugenholtz vd., 2013; Cryderman vd., 2014; Shahbazi vd., 2015; Eltner vd., 2016; Bui vd., 2017; Gorkovchuk vd., 2017; Rossi vd., 2017; Ulusoy vd., 2017; Seki vd., 2017; Beretta vd., 2018). Literatürde yer alan bu çalışmalarda, İHA ölçümlerine dayalı uygulama sonuçlarının bilimsel açıdan kabul edilebilir doğruluk ve hassasiyette olduğu belirtilmiştir.

Bu çalışmaların yanı sıra İHA fotogrametrisi 2010 yılından sonra plaka hareketlerinin, büyük ölçekli heyelanların ve deformasyonların izlenmesi içinde kullanılmaya başlanılmıştır (Niethammer vd., 2012; Bing-jun vd., 2013; McLeod vd., 2013; Tong vd., 2015; Immerzeel vd., 2014; Deffontaines vd., 2016; Hemmelder vd., 2018; Gül vd., 2018). Niethammer vd., (2012) çalışma sahasına ait periyodik SYM'ler oluşturarak bu SYM'ler arasındaki farklardan deformasyonları belirlemeye çalışmışlardır. Rau vd. (2011) heyelan tespiti ve bitki endeksleri hesaplamasını gerçekleştirmek için sabit kanatlı bir platform, Carvajal vd. (2011) ise yol güzergâhlarında heyelanların karakterize edilmesi için 12 Mp'lik bir kamera taşıyan dört motorlu bir kopter kullanmışlardır. Niethammer vd. (2011) açık kaynaklı bir yazılım ile orto-mozaik ve SYM'nin oluşturulması yoluyla heyelanların izlenmesine 
dönük bir araştırma gerçekleştirmiştir. Shi vd. (2011) İHA tabanlı altyapı izleme uygulamalarını hedefleyen, büyük deformasyonlara uğrayan cisimlerin tespiti üzerine çalışma yapmışlardır. Aynı zamanda İHA ile elde edilen yüksek çözünürlüklü SYM ve ortofotolar kullanılarak mostra vermiş yüzey kırıkları belirlenmeye çalışılmıştır. Bunun yanı sıra InSAR tekniği ile İHA verileri birlikte kullanılmış, İHA ile elde edilen yüksek çözünürlükteki SYM'ler InSAR değerlendirmeleri için altlık olarak kullanılmıştır. Deffontaines vd. (2016) yapisal aktif tektonik geometrinin deşifre edilmesi için, yerel aktif tektonik kilit alanlarda yüksek çözünürlüklü SYM elde etmek için İHA'ları kullanmıştır. Mostra veren aktif deformasyonlar mevcut GPS verileri ve PALSAR interferometrisi ve İHA verileri ile birlikte yorumlanmıştır. Gül vd. (2018) üç farklı mermer firmasının, Amasya İli Eliktekke köyü mevkiinde bulunan ve kendi ruhsat alanlarında olmak üzere ancak sınırlarda bitişik olan pasa döküm sahası şevlerindeki deformasyonları GNSS yönteminin yanı sıra İHA fotogrametrisiyle de 4 periyot izleyerek İHA verilerine dayalı deformasyon haritaları üretmişlerdir.

Yukarıda verilen bilgiler 1şı̆̆ında İHA'ların kullanımının madencilik sektöründe yaygınlaştırılması birçok avantaj sağlayacaktır. Özellikle açık maden işletmelerinde kısa zaman aralıklarıyla üretim, dekapaj, stok ve döküm miktarı hesabı yapılması için periyodik haritalama çalışması gerekmektedir. Yersel yöntemler ile bu çalışmanın yapılması iş güvenliği açısından risklere, yüksek maliyetlere ve zaman kayıplarına yol açmaktadır. Buna karşın İHA kullanılarak periyodik ortofoto haritaların üretimi oldukça düşük maliyetli ve zaman, personel açısından kıyaslanamayacak kadar avantajlıdır. Bunun yanı sıra İHA ile, k1smi haritalama yerine yani sadece çalışmanın yapıldığı alanın değil tüm maden sahasının periyodik haritaları üretilebilmektedir. $\mathrm{Bu}$ sayede çalışma sahasında olası tehditler öngörülebilecek geleceğe yönelik sağlıklı kararlar alınarak optimum planlama yapılması söz konusu olabilecektir.

\section{AÇIK MADEN IŞSETMELERINDE İHA FOTOGRAMETRISII UYGULAMALARI}

İHAfotogrametrisiileistenilenamaç doğrultusunda haritalar üretebilmek, geleneksel yöntemlere göre çok daha kısa sürelerde, minimum operasyonel ekip ve daha düşük maliyetler ile mümkündür. $\mathrm{Bu}$ kapsamda açı maden işletmelerine dönük İHA tabanlı örnek uygulamalar ve ayrıntıları aşağıda verilmektedir. $\mathrm{Bu}$ örnekler; yazarın araştırmacı olarak yer aldığ 02.03 .2017 tarih ve 2017-5872/1 nolu KOSGEB tarafindan Ar-Ge, İnovasyon ve Endüstriyel Uygulama Destek Programı kapsamında desteklenen ve halen devam eden "İnsansız Hava Aracı (İHA) İle Açık Maden İşletmelerinde Yüksek Çözünürlüklü Sayısal Arazi Modelleri, Hâlihazır Haritalarının Yapımı ve Alansal Deformasyonların İzlenmesi için MineGeoP Yazılımının Geliştirilmesi” konulu proje çalışmaları ve yine yazarın Cumhuriyet Teknokent (Sivas) üzerinden yürütücü ya da araştırmacı olarak çalıştığı özel sektör hizmet sözleşmeleri kapsamında elde edilen verilerin değerlendirilmesi sonucunda üretilmiştir.

İHA fotogrametrisiyle üretilen bir halihazır harita üretiminin aşamaları, aşağıda verildiği gibidir (Şekil 1).

- Uçuş planının hazırlanması (Şekil 1a),

- Yer Kontrol Noktası (YKN) lokasyonlarının belirlenmesi, arazide tesisi ve ölçümü (Şekil 1b),

- Uçuşun gerçekleştirilmesi (Şekil 1c),

- Hava fotoğraflarının değerlendirilmesi (Şekil 1d, e, f),

- Ortofoto (Şekil 1g), nokta bulutu (Şekil 1h) ve Sayısal Yükseklik Modelinin (Şekil 1i) oluşturulması,

- Krymetlendirme işleminin gerçekleştirilmesi ve halihazır harita üretimi (Şekil 1j). 
Yavuz GÜL
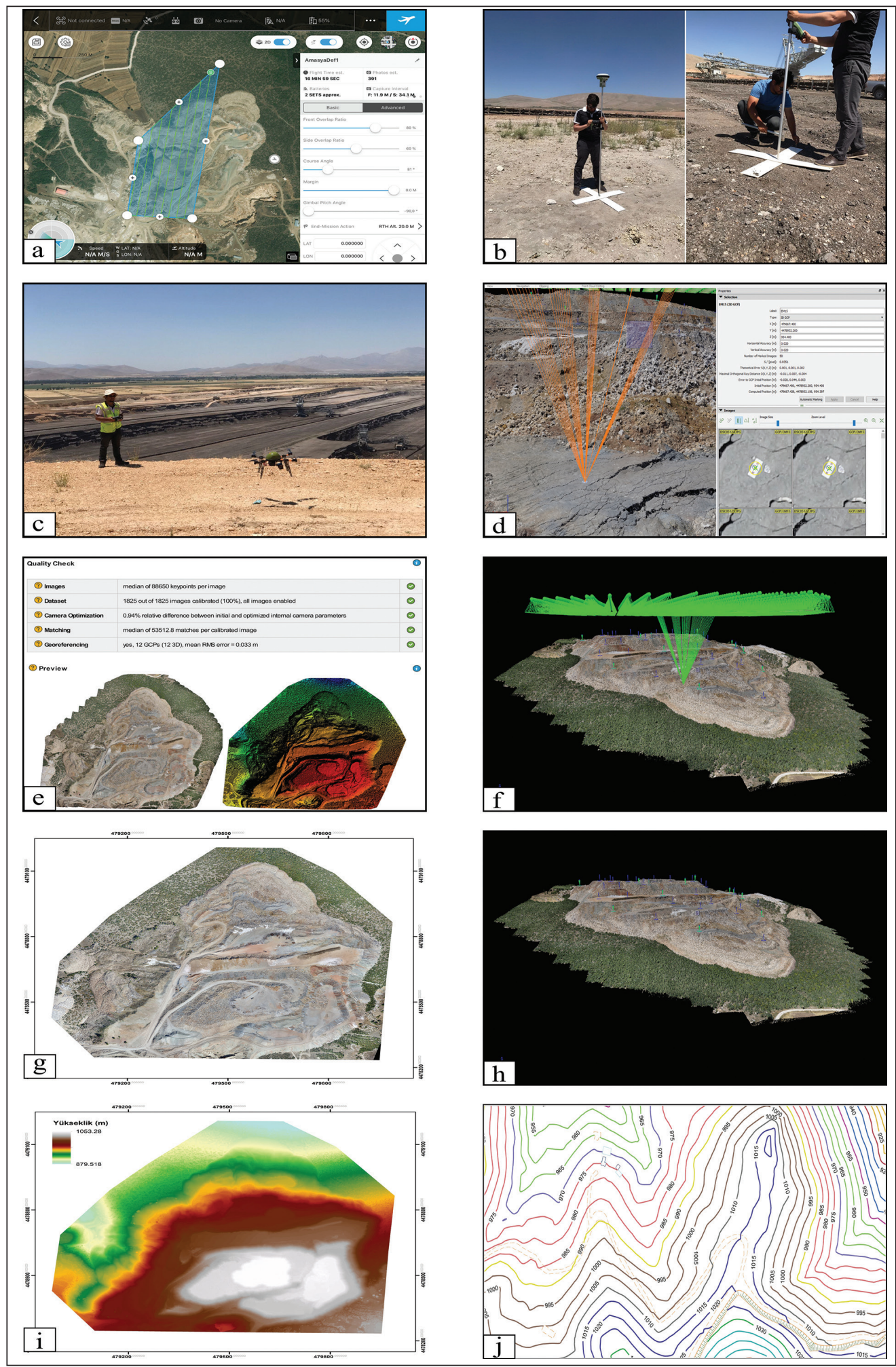

Şekil 1. İHA fotogrametrisi kullanılarak halihazır harita üretim aşamaları.

Figure 1. Base map production stages by using UAV photogrammetry. 
İHA fotogrametrisi ile aynı çalışmanın çıtıtı ürünü olarak ortofoto, SYM, nokta bulutu ve 3D model üretilmektedir. $\mathrm{Bu}$ yöntemin en büyük avantajıdır. Nokta bulutları yüksek çözünürlükte olup genellikle 2-10 cm arasında hassasiyetle üretilmektedir. $\mathrm{Bu}$ durum çalışma sahasının tamamına ait istenilen çözünürlükte nokta bulutunun oluşturulmasına imkân sağlamaktadır. Şekil 2'de Karaman ilinde bir açık mermer ocağ işletmesine ait ortofoto, SYM, 3D model ve nokta bulutu, Şekil 3'de Kahramanmaraş ili Elbistan ilçesinde bulunan bir kömür işletmesine ait ortofoto ve SYM sunulmaktadır. Bu ürünler, GEOMINE Arge Yazılım şirketine ait üzerinde
Sony A6000 kamera (24 Mp) bulunan Teknomer marka Quadrocopter ile aydinlanmanın en uygun olduğu 10:00 ile 14:00 saatleri arasında, 120 metre yükseklikten, $\% 80$ boyuna ve $\% 60$ enine bindirme oranlarında yapılmış İHA uçuşlarından elde edilmiştir (Şekil 2, 3). İHA fotogrametrisi ile üretilen nokta bulutu (Şekil 2) incelendiğinde, yersel yöntemle ulaşılamayacak şev diplerin de dahi çözünürlüğü ve konum doğruluğu çok yüksek nokta kümeleri görülmektedir. Bu durum yersel yöntemle alım gerçekleştirilemeyecek dik ve erişilemeyen alanlarda da İHA fotogrametrisinin üstünlüğünü göstermektedir.

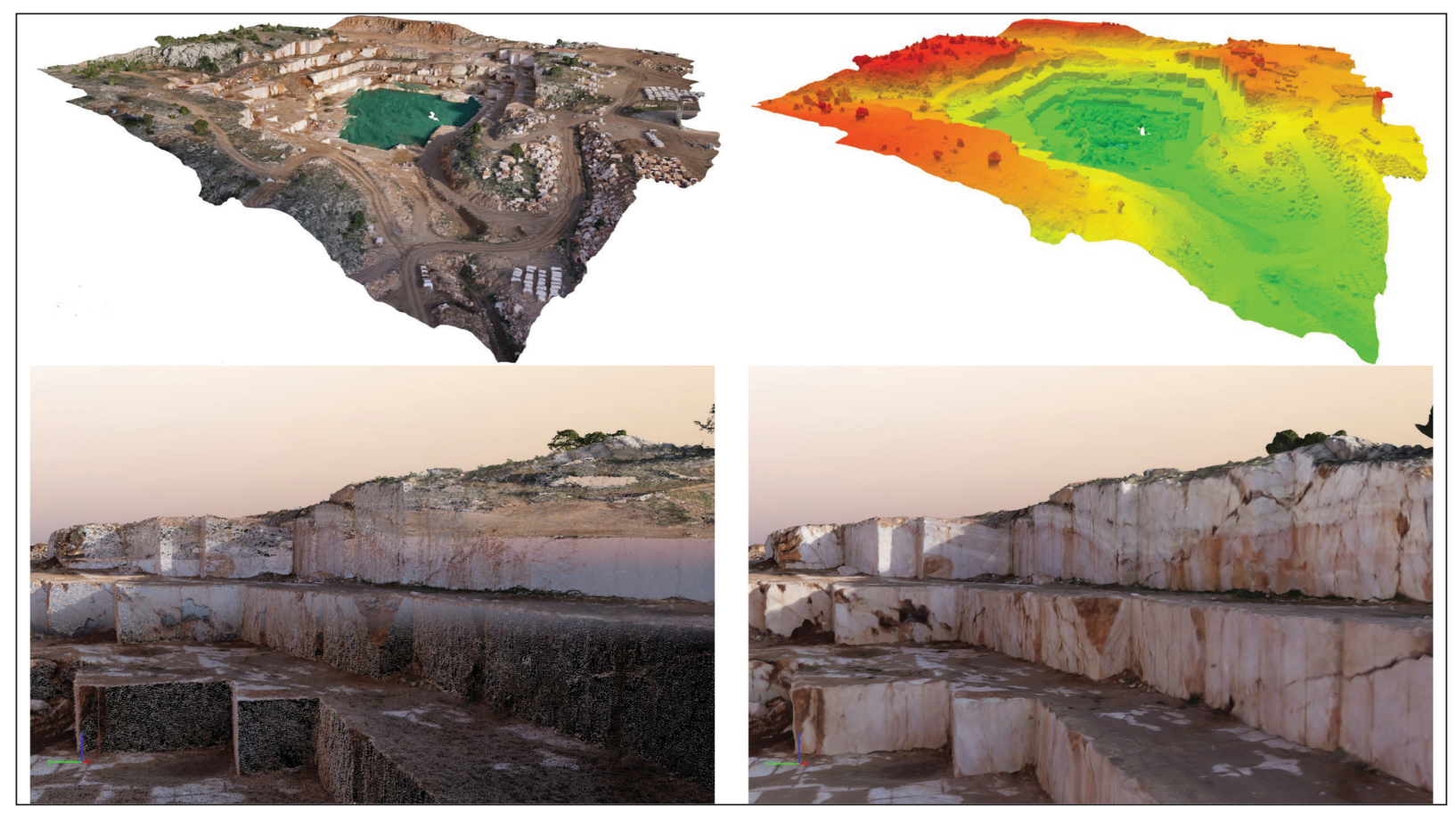

Şekil 2. Bir mermer ocağının ortofoto, SYM, nokta bulutu ve 3D modeli.

Figure 2. Orthophoto, DEM, point cloud and $3 D$ model of a marble quarry. 

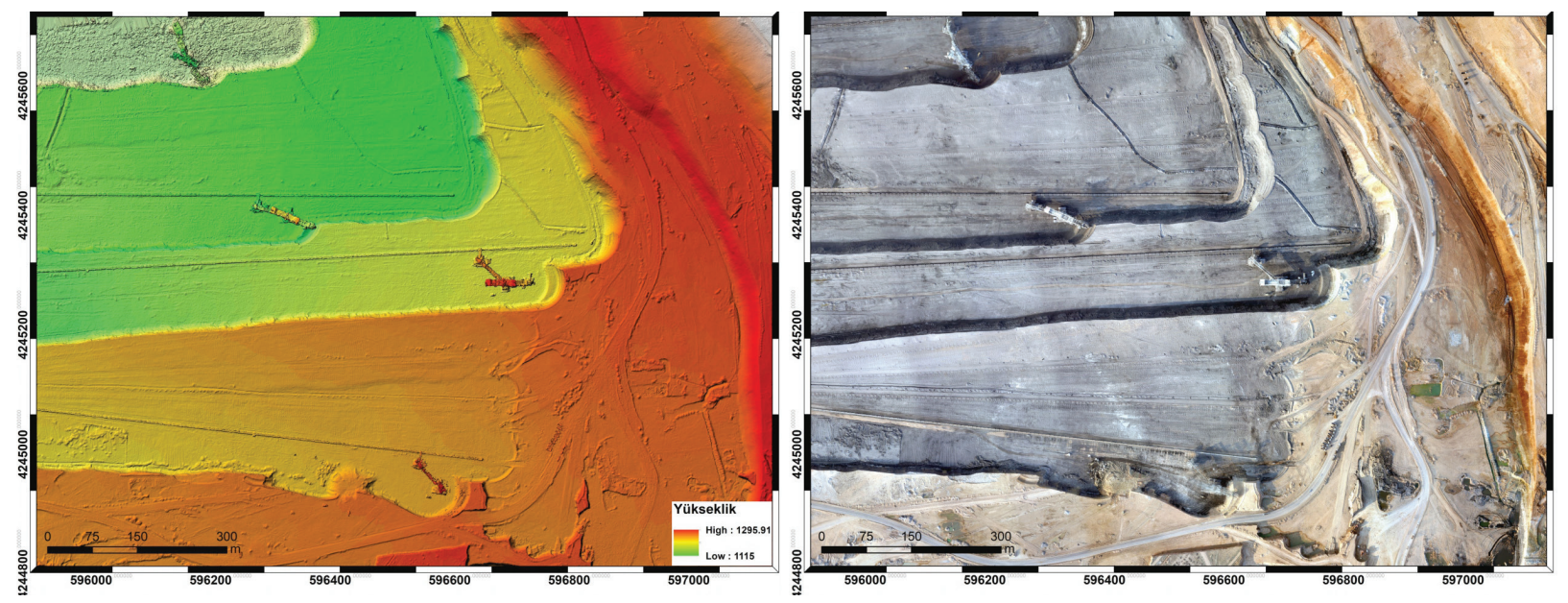

Şekil 3. Bir kömür açık işletmesinin SYM ve ortofotosu.

Figure 3. DEM and orthophoto of an open-pit coal mine.

Maden sahalarında İHA fotogrametrisi kullanılarak gerçekleştirilen çalışmalar sadece halihazır harita üretimi ile sinırlı olmayıp ortofoto, nokta bulutu ve SYM ürünleri ve bu ürünlere dayalı özel çözümlere de imkân sağlamaktadır. Şekil 4 ve 5'te Pix4D programının açık kaynak fotoğraflarının (Url-1) değerlendirilmesiyle oluşturulmuş bir açık ocakta 3D model ve nokta bulutu kullanılarak elde edilebilen bazı önemli parametreler özetlenmiştir. İHA fotogrametrisi ile üretilen 3D modeller üzerinden alan, kübaj, dolgu miktarı ve dekapaj hesaplarının yanı sıra basamak açısı, genişliği ve yüksekliği, genel şev açısı ve özellikle anlık örtü-kazı oranları gibi parametreler çok kısa sürelerde zahmetsizce belirlenebilmektedir. Maden sahalarında optimum üretim planlaması için gerekli olan ve 1 ton cevher üretimi için yapılması gereken dekapaj miktarını gösteren örtü-kazı oranlarının belirlenmesi maliyet hesaplamaları açısından çok önemli bir konudur. İHA fotogrametrisi ile üretilen nokta bulutu ve SYM'ler kullanılarak çalışma yapılacak bölgelerdeki örtü kazı oranları çalışma öncesinde kolaylıkla hesaplanabilmekte ve bu değerler 3D model üzerinde simüle edilmektedir. Şekil 5'de mevcut bir üretim basamağından yapılacak kazı miktarı ve kazı sonrası oluşacak arazi modelinin simülasyonu bulunmaktadır. Bunun yanı sıra 3D modeller üzerinde herhangi bir kazı planlaması, uygulama öncesi simülasyonlar oluşturularak kullanıc1lara sunulabilmektedir. Şekil 6'da Sivas ili Kangal ilçesi Yellice köyü mevkiinde, planlama aşamasında olan bir krom cevher hazırlama tesisi kurulum yerinin ve alanda yapılacak kazının simülasyonu görülmektedir. Maden işletmelerinin özellikle stok hacimlerinin düzenli aralıklarla bilinmesi, ocağın optimize edilmesi, üretimin sürekliliğinin sağlanması ve satış politikalarının oluşturulması için çok önemlidir. 


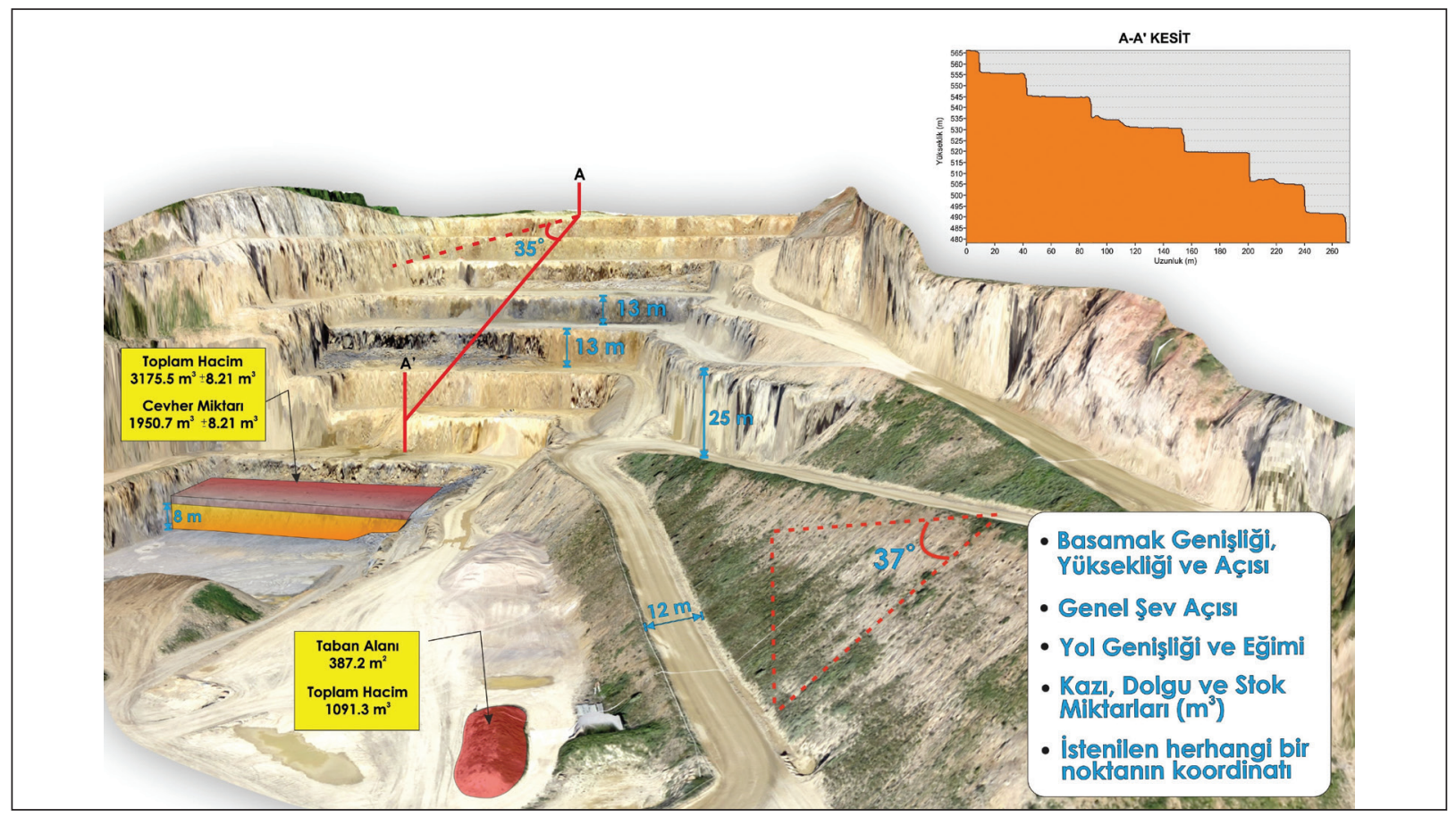

Şekil 4. Açık ocaklarda 3D model kullanılarak elde edilebilen bazı önemli parametreler.

Figure 4. Some important parameters obtained by using 3D model in open-pit mines.

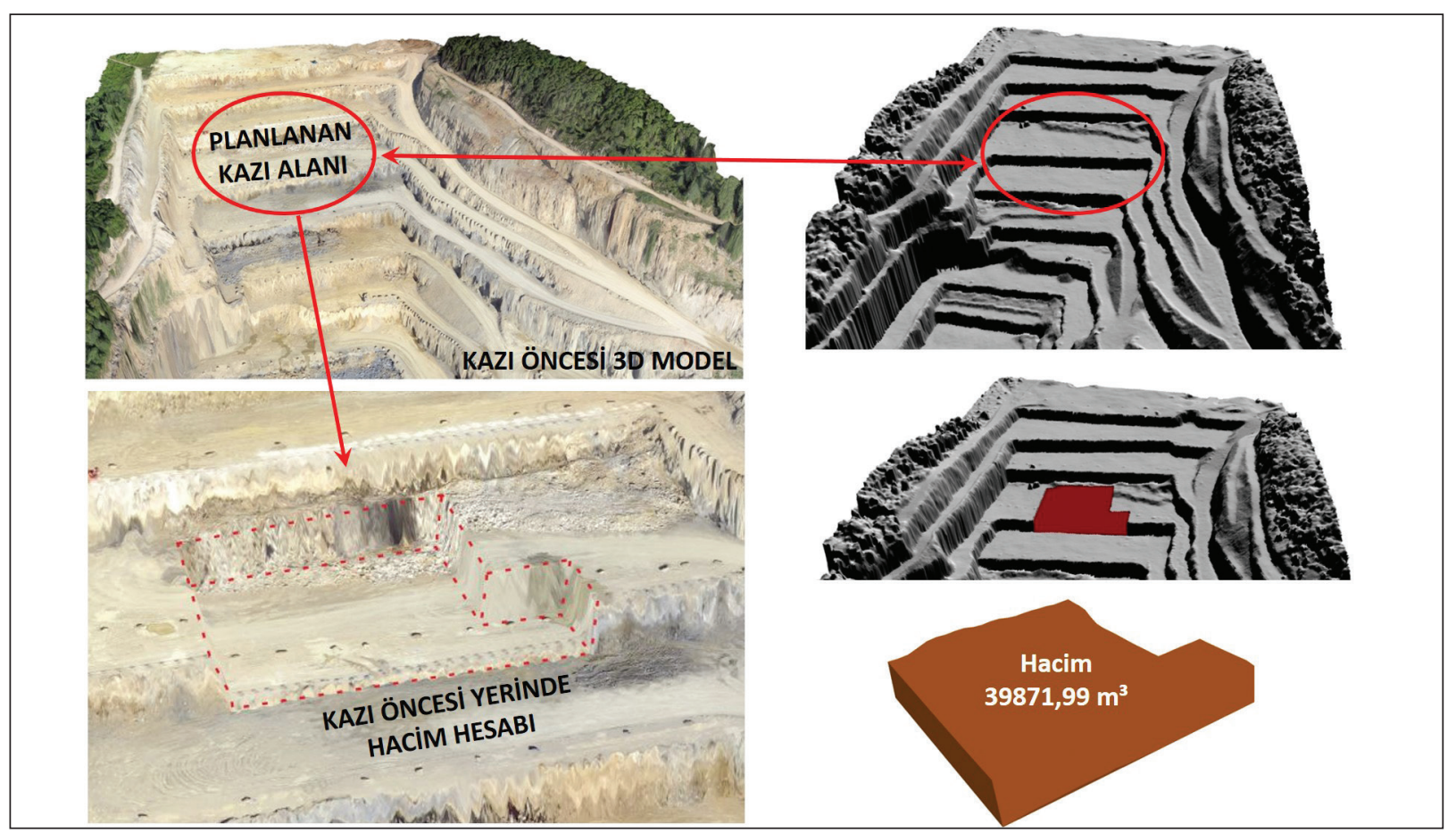

Şekil 5. 3D model simülasyonu kullanılarak hesaplanan kazı (yerinde) miktarı.

Figure 5. Excavation amount (in-situ) calculated by using 3D model simulation. 


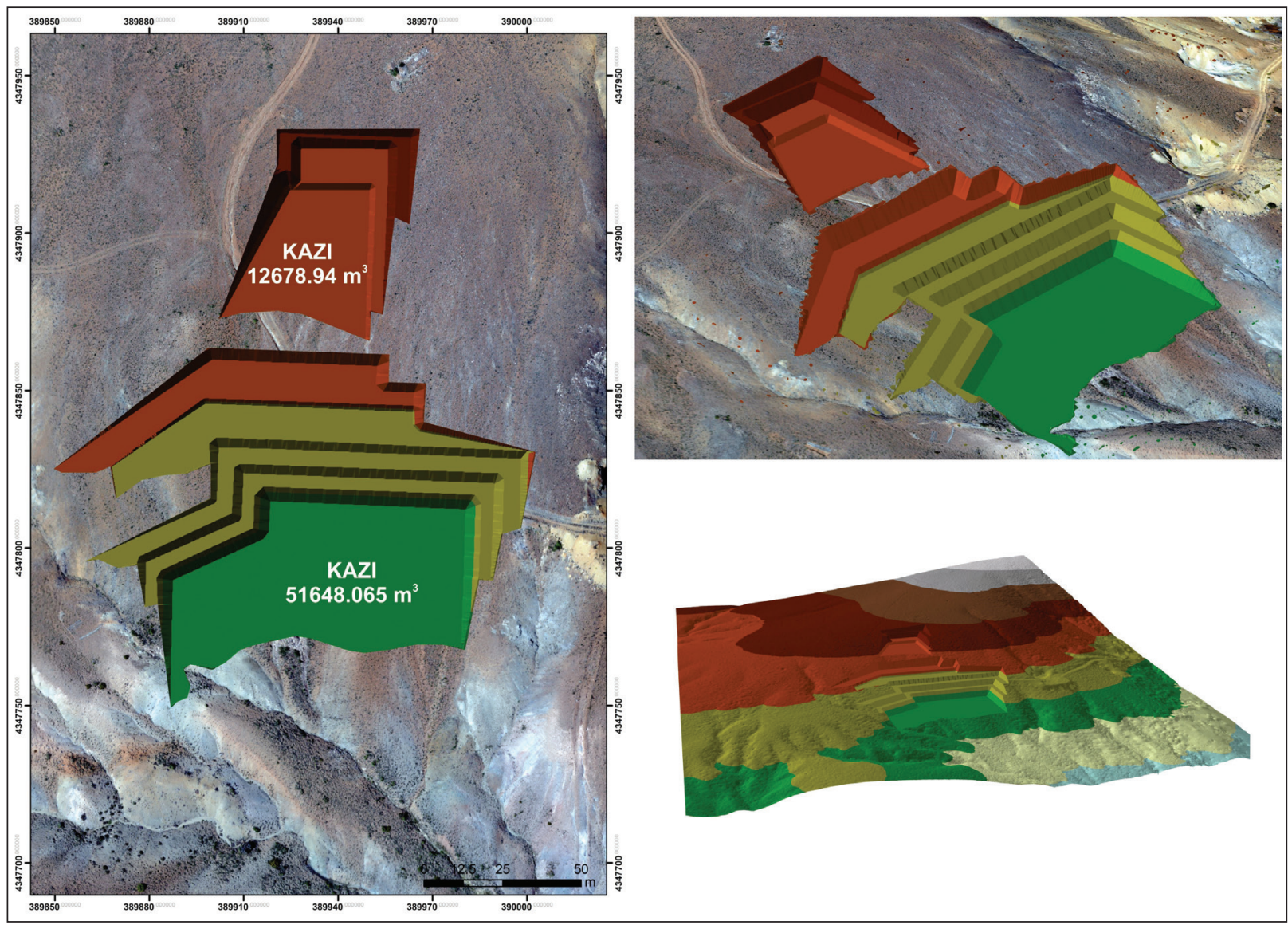

Şekil 6. Cevher hazırlama tesisinin planlanmasında kazı simülasyonu.

Figure 6. Excavation simulation of mineral processing plant planning.

Ayrica İHA fotogrametrisi ile kazı alanı ve civarı ile döküm sahalarındaki olası deformasyonlardaalansalolarakizlenebilmektedir. Şekil 7'de Amasya İli Eliktekke köyü mevkiinde bulunan bir mermer ocağına ait deformasyon haritası verilmiştir. Bu harita İHA ile belirli zaman aralıklarında gerçekleştirilen uçuşlar sonucunda elde edilen ortofoto ve SYM'lerden üretilmiştir. Açık maden işletmelerinde oluşabilecek deformasyonların belirlenmesi ve izlenmesi gerek can güvenliği gerekse üretimin sürekliliği açısından oldukça büyük öneme sahiptir. İHA fotogrametrisi ile deformasyon izlemede; izlenecek alana istenilen hassasiyete bağlı olarak belirli sayıda YKN tesis edilmekte ve alan periyodik İHA uçuşlarıyla takip edilmektedir. İHA uçuşlarından elde edilen ortofotolar değerlendirilerek zamana bağlı deformasyon haritaları üretilmektedir. Olası deformasyonların İHA fotogrametrisiyle izlenmesi, tehdit oluşturabilecek bölgelerin hızla belirlenmesine ve hareketin büyüklüğüne göre gerekli önleyici tedbirlerin alınarak olası kaymaların engellenmesine imkân sağlamaktadır. 


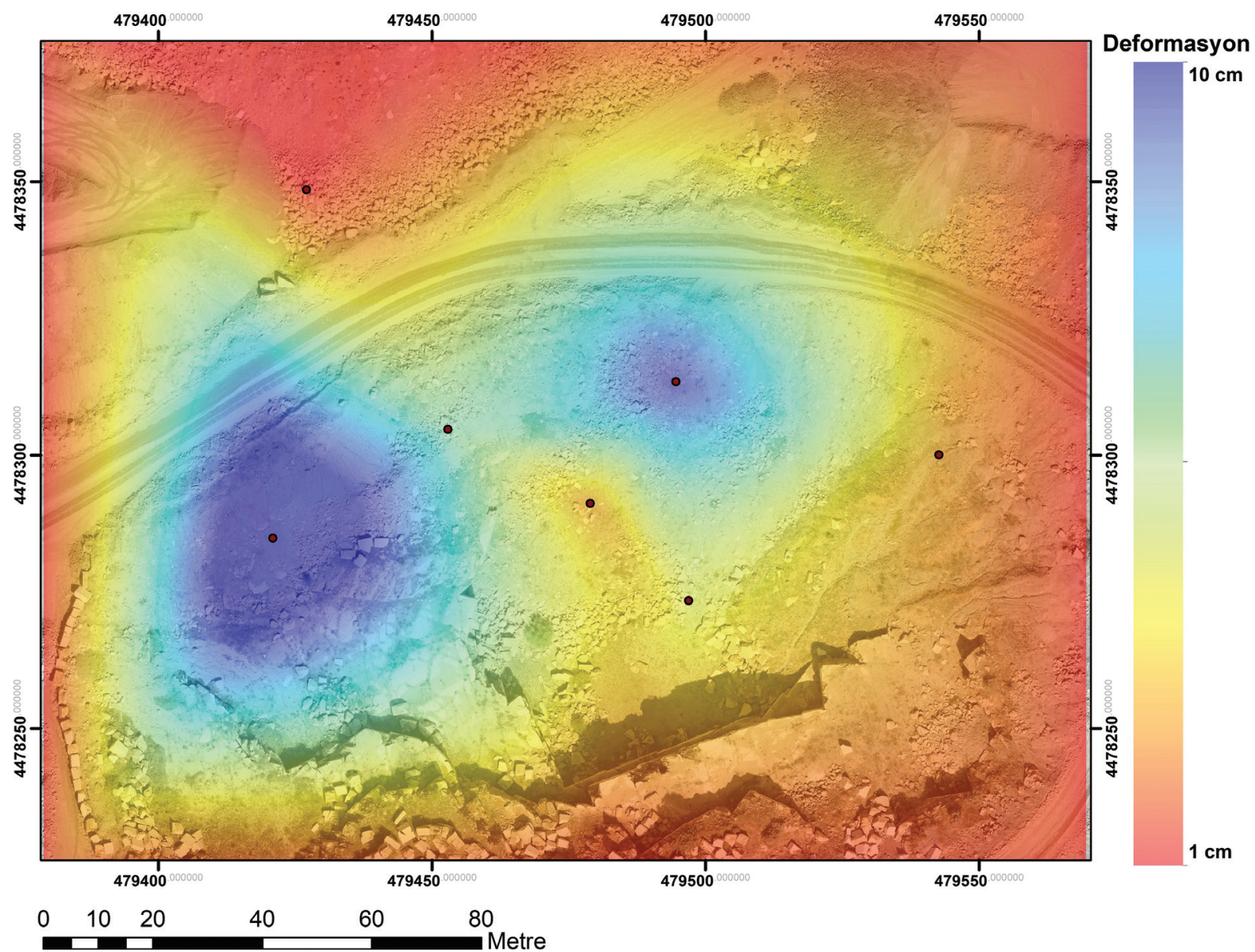

Şekil 7. Bir mermer ocağında İHA kullanılarak deformasyon analizi.

Figure 7. Deformation analysis by using UAV in a marble quarry.

\section{SONUÇLAR}

Maden işletmelerinin en temel ihtiyacı, yüksek konum bilgisine sahip altlık haritaların sık aralıklı üretilmesidir. Konum bilgisi yüksek, güncel ve periyodik olarak hazırlanan bu haritalar sayesinde ileriye yönelik üretim planlaması daha doğru bir şekilde yapılabilir. İHA'nın istenildiği anda ve zor koşullarda hızlı veri elde edebilme yeteneği, onu diğer yöntemlere göre ön plana çıkarmaktadır.

İnsansız hava araçları ile yapılan uçuşlar sonrasinda elde edilen yüksek hassasiyetli 3D arazi modeli, ortofoto ve yoğun renkli nokta bulutu sonuç ürünleri kullanılarak; maden üretim ve kazı haritalarının hazırlanması, stok ve döküm sahalarında yüksek doğrulukta kübaj hesab1, anlık örtü-kazı oranları ve dolgu miktarlarının tespiti, arazi ve sayısal yükseklik modeli ile yüzey topografyasının belirlenmesi, potansiyel kazalara yol açmadan önce olası deformasyon tehlikelerini tespit etmek ve tanımlamak, kazı planlaması, ocak geometrisinin (basamak şev açısı, genişliği ve yüksekliği, genel şev açıları) takibi, hiperspektral kameraların takılması ile beraber alterasyon ve mineral tespiti yapılması mümkündür.

Yersel yöntemler ile yukarıda işaret edilen çalışmaların yapılması uzun zaman ve emek gerektirmekte, ölçümler sırasında üretim sekteye uğrayabilmektedir. Bununla birlikte iş güvenliği 
açısından da riskli durumlar ortaya çıkabilmekte olup tüm bu çalışmalar maliyet yönünden oldukça külfetli olmaktadır. İHA ile üretilecek sayısal veriler klasik yersel ölçü yöntemlerine (Total Station, GPS) göre çok daha kısa zaman aralığında, minimum operasyonel ekip ve daha az maliyet ile ortaya konulabilmektedir. Bunun yanı sira 3D model, ortofoto ve nokta bulutu ürünleri aynı çalışma içerisinde elde edilebildiğinden bu ürünler spesifik çözümlere de imkân sağlamaktadır. İHA kullanılarak periyodik ortofoto haritaların üretimi ve özellikle stok miktarı ile dekapaj hesabı oldukça düşük maliyetli ve zaman-personel açısından da kıyaslanamayacak kadar avantajlıdır. Ayrıca İHA kullanılarak kısmi haritalama yerine yani birçok maden işletmesinde uygulandığ 1 şekliyle sadece güncel çalışma alanının değil her seferinde tüm maden sahasının periyodik olarak haritalanması söz konusudur.

Sonuç olarak ülkemizde de birçok alanda yaygın olarak kullanılmaya başlanılan İHA fotogrametrisinin, açı maden işletmelerinde de kullanılması gerek emek-zaman gerek iş güvenliği gerekse maliyet açısından büyük avantajlar sağlayacaktır. Bu bağlamda İHA ile zorlu arazi şartlarında kolay, hızlı, yüksek hassasiyetli ve ekonomik ölçümler yapılabilmektedir. Kısa sürede üretilen 3D modeller; üretim ve kazı ilerlemelerinin izlenmesi, tutarsızlıkların belirlenerek ileriye dönük sağlıklı karar verilebilmesi ve planlama açısından son derece kolay çözümler sunmaktadır.

\section{KATKI BELIRTME}

$\mathrm{Bu}$ çalışmaya katkı sağlayan 02.03.2017 tarih ve 2017-587-2/1 nolu KOSGEB projesi Ar-Ge ekibi üyeleri Doç.Dr. K. Özgür HASTAOĞLU ve Doç. Dr. Fatih POYRAZ'a, donanım, yazılım ve arşiv desteğinden dolayı Geomine Ltd. Şti. ile şirket çalışanları Burak Can KARA ve Mehmet Akif ŞAHIN'e ayrıca şirket stajyeri Erdemcan HASTAOĞLU'na teşekkür ederim.

\section{EXTENDED SUMMARY}

Unmanned aerial vehicle (UAV) platforms are currently important data sources allowing the possibility of audit, observation and analysis in different disciplines and different application areas for production of photogrammetric data. UAV provide important contributions to disciplines related to the earth sciences like mapping, mining, geology, construction and environmental engineering as they can be easily used for rapid and economic access to current data. Due to developing photogrammetric sensors, platform and remote sensing technologies, UAV is becoming a more common platform due to its capability to provide high spatial and temporal resolution capabilities compared to classic air photogrammetry.

$A$ variety of studies in the recent past have assessed the photogrammetric potential of UAV. They are used in many applications. In addition to these studies, research continues to increase the accuracy of orthophoto maps and digital elevation models (DEM) obtained (Harwin ve Lucieer, 2012; Barry ve Coakley, 2013; Udin ve Ahmad, 2014; Cryderman et al., 2014; Babinec ve Apeltauer, 2016; Kılınçoğlu, 2016; Popescu ve Paunescu, 2016; Kršák et al., 2016; Ulusoy et al., 2017; Yusoff et al., 2017).

In line with these developments in UAV photogrammetry, studies such as current map production of open-pit mines, three-dimensional (3D) modelling, determination of production and stripping amounts, calculation of stock and dumpsite cubage, rock identification, geological mapping, excavation planning and alteration and mineral identification with hyperspectral cameras and mapping of vertical and inaccessible points have used this method (Câmara et al., 2013; Hugenholtz et al., 2013; Cryderman et al., 2014; Shahbazi et al., 2015; Eltner et al., 2016; Bui et al., 2017; Gorkovchuk et al., 2017; Rossi et al., 2017; Ulusoy et al., 2017; Beretta et al., 
2018). In addition to these studies, since 2010 UAV photogrammetry has begun to be used to observe plate movements, large-scale landslides and deformations (Niethammer et al., 2012; Bingjun et al., 2013; McLeod et al., 2013; Tong et al., 2015; Immerzeel et al., 2014; Deffontaines et al., 2016; Hemmelder et al., 2018; Gül et al., 2018). These studies have stated the results of applications with UAV-based measurements have scientifically acceptable accuracy and sensitivity.

In light of the information above, more common use of UAVs in the mining sector will provide many advantages. The most basic requirement of mine operators is the production of base maps with high location information at frequent intervals. Due to these maps with high location information prepared currently and periodically, future production planning can be made more accurately. The ability of UAV to obtain data at the desired time and in difficult conditions with minimal operational team and low cost brings it to the forefront compared to other methods.

This study explains the advantages of UAV-based mapping applications for open pit operations. Within this scope, UAV-based example applications and details related to open pit operations are given below. These examples were produced as a result of assessing data obtained in the project studies entitled "Development of MineGeoP software for high-resolution digital field models, construction of existing maps and observation of aerial deformations with unmanned aerial vehicle (UAV) in open pit operations" supported by KOSGEB within the scope of the $R$ \& $D$, Innovation and Industrial Application Support Program dated 02.03.2017 number 2017-587-2/1 in which the author was a researcher and from a private sector agreement in which the author worked as organizer or researcher via Cumhuriyet Teknokent (Sivas).

The stages of producing an existing map using $U A V$ photogrammetry are given in Figure 1. The same study with the UAV photogrammetry can produce orthophotos, DEM, point clouds and $3 D$ models as outputs. This is the greatest advantage of the method. Point clouds can have any desired resolution but are generally produced with sensitivity from $2-10 \mathrm{~cm}$. This situation allows the possibility of creating a point cloud at the desired resolution for the whole study area. Figure 2 presents the orthophoto, DEM, 3D model and point cloud for an open pit marble quarry in Karaman province, while Figure 3 presents the orthophoto and DEM of a coal mine in Elbistan county in Kahramanmaras. When the point cloud produced with the UAV photogrammetry is investigated, point clusters with very high location accuracy and resolution including scarp dips that cannot be reached by terrestrial methods are observed. This situation shows the superiority of the UAV photogrammetry in vertical and inaccessible areas where inputs cannot be obtained with terrestrial methods.

Studies completed using UAV photogrammetry in mine sites are not only limited to producing existing maps, but allow the production of orthophoto, point clouds and DEM products and specific solutions based on these products. Figure 4 displays a 3D model of an open pit creased from sample photographs (Url-1) in the Pix $4 D$ program and some important parameters obtained using the point cloud are summarized. In addition to the area, cubage, fill amounts and strip calculations on the $3 D$ models produced with UAV photographs, parameters like the angle, width and height of the benchs, overall slope angle and especially instantaneous stripping ratio can be easily determined in very short times.

Additionally, any excavation plan on $3 D$ models can be used to create pre-application simulations for users. An open-pit mine produced from sample photographs in the Pix 4 D program (Url-1) and another simulation related to the excavation amount calculation on a 3D model are given in Figure 5. In Figure 5, the excavation 
amount for the present production stage and the simulation of the field model that will be formed after excavation are given. Figure 6 shows the simulation of the location site for a chrome mineral processing plant and excavation to be performed in the area in the planning stages in Yellice village in Kangal county in Sivas. Knowing stock volumes for mining operations at regular intervals is very important for optimizing the pit, ensuring continuous production and forming sales policies.

Additionally, possible deformations in the excavation area and surroundings and dump sites can be spatially observed with the UAV photogrammetry. Figure 7 gives the deformation map of a marble quarry found in Eliktekke village in Amasya province. This map was produced from orthophoto and DEMs obtained from flights completed at certain intervals with the UAV. Determination and observation of deformations that can form in open-pit mines has great importance in terms of safety and continuation of production.

The above-mentioned studies with terrestrial methods take a long time and high effort and production may have to cease during measurements. Additionally, risky situations in terms of occupational safety may occur, and the cost of these studies is burdensome. Digital data produced with UAV can be obtained in an interval shorter compared to classic terrestrial measurement methods (total station, GPS), with minimum operational team and with at a lower cost. Additionally, using the UAV, periodic mapping of the whole mine site can be completed each time, instead of partial mapping of the current working area as used in many mine operations.

In conclusion, the UAV photogrammetry beginning to be commonly used in many areas Turkey, will ensure great advantages in terms of effort-time, work safety and cost if used for open-pit mines. In this context, measurements with UAV can be easily and rapidly performed with high sensitivity and economy in difficult field conditions. 3D models produced in short time present easy solutions for observation of production and excavation advances, the ability to make healthy forward-looking decisions by determining inconsistencies and in terms of the planning stages.

\section{ORCID}

Yavuz Gül (D) https://orcid.org/0000-0002-2969-577X

\section{DEĞIINILEN BELGELER}

Akyürek, S., Yılmaz, M.A., Taşkıran, M., 2012. İnsansız hava araçları: Muharebe alanında ve terörle mücadelede devrimsel dönüşüm. Bilge Adamlar Stratejik Araştırmalar Merkezi Yayınları, Rapor no: 53, İstanbul, $63 \mathrm{~s}$.

Babinec, A., Apeltauer, J., 2016. On accuracy of position estimation from aerial imagery captured by low-flying UAVs. International Journal of Transportation Science and Technology, 5(3), 152-166.

Barry, P., Coakley, R., 2013. Accuracy of UAV photogrammetry compared with network RTK GPS. Int. Arch. Photogramm. Remote Sens, 2, 27 31.

Beretta, F., Shibata, H., Cordova, R., Peroni, R.D.L., Azambuja, J., Costa, J.F.C.L., 2018. Topographic modelling using UAVs compared with traditional survey methods in mining. REM-International Engineering Journal, 71(3), 463-470.

Bing-jun S, Xu L, Lin-xiu L., 2013. Application of UAV in open-pit mine disaster monitoring. Opencast Mining Technology, 6, 69-71.

Bui, D.T., Long, N.Q., Bui, X.N., Nguyen, V.N., Van Pham, C., Van Le, C., Kristoffersen, B., 2017. Lightweight unmanned aerial vehicle and structure-from-motion photogrammetry for generating digital surface model for openpit coal mine area and its accuracy assessment. In International Conference on Geo-Spatial Technologies and Earth Resources, Springer, Cham, 17-33. 
Câmara, T., Fontoura, D., Peroni, R., Capponi, L., 2013. Controlling dilution and mine planning. 36th APCOM symposium applications of computers and operations research in the mineral industry, Porto Alegre, Brazil, 1-10.

Carvajal F, Agüera F, Pérez M., 2011. Surveying a landslide in a road embankment using unmanned aerial vehicle photogrammetry. ISPRS Zurich 2011 Workshop, International Archives of Photogrammetry Remote Sensing and Spatial Information Sciences, 38(1/C22), 201-206.

Cryderman, C., Mah, S.B., Shufletoski, A., 2014. Evaluation of UAV photogrammetric accuracy for mapping and earthworks computations. Geomatica, 68(4), 309-317.

Deffontaines, B., Chang, K.J., Champenois, J., Fruneau, B., Pathier, E., Hu, J.C., Liu, Y.C., 2016. Active interseismic shallow deformation of the Pingting terraces (Longitudinal Valley-Eastern Taiwan) from UAV high-resolution topographic data combined with InSAR time series. Geomatics, Natural Hazards and Risk, 8(1), 120-136.

Eltner, A., Kaiser, A., Castillo, C., Rock, G., Neugirg, F., Abellán, A., 2016. Image-based surface reconstruction in geomorphometry-merits, limits and developments. Earth Surface Dynamics, 4(2), 359-389.

Gonçalves, J. A., Henriques, R., 2015. UAV photogrammetry for topographic monitoring of coastal areas. ISPRS Journal of Photogrammetry and Remote Sensing, 104, 101-111.

Gorkovchuk, D., Gorkovchuk, J., Hutnyk, B., 2017. Low-cost UAS photogrammetry for mining. GIM International, The Global Magazine for Geomatics, 31(11), 20-23.

Gül, Y., Hastaoğlu, K.Ö., Poyraz, F., 2018. Fimar, Emmioğlu ve Alternatif Mermer A.Ş.'ye ait Amasya mermer ocağı döküm sahası şevlerinde deformasyonların jeodezik yöntemle izlenmesi ve değerlendirilmesi. Nihai Rapor, Sivas Cumhuriyet Üniversitesi Mühendislik Fakültesi, Sivas, 52 s.

Harwin, S., Lucieer, A., 2012. Assessing the accuracy of georeferenced point clouds produced via multiview stereopsis from unmanned aerial vehicle (UAV) imagery. Remote Sensing, 4(6), 15731599.
Hemmelder, S., Marra, W., Markies, H., De Jong, S. M., 2018. Monitoring river morphology \& bank erosion using UAV imagery-A case study of the river Buëch, Hautes-Alpes, France. International Journal of Applied Earth Observation and Geoinformation, 73, 428-437.

Hugenholtz, C.H., Whitehead, K., Brown, O.W., Barchyn, T.E., Moorman, B.J., LeClair, A., Hamilton, T., 2013. Geomorphological mapping with a small unmanned aircraft system (sUAS): Feature detection and accuracy assessment of a photogrammetrically-derived digital terrain model. Geomorphology, 194, 16-24.

Immerzeel, W.W., Kraaijenbrink, P.D.A., Shea, J.M., Shrestha, A.B., Pellicciotti, F., Bierkens, M.F.P., De Jong, S.M., 2014. High-resolution monitoring of Himalayan glacier dynamics using unmanned aerial vehicles. Remote Sensing of Environment, 150, 93-103.

Kılınçoğlu D.B., 2016. Farklı insansız hava araçları ile elde edilen görüntülerin otomatik fotogrametrik yöntemlerle değerlendirilmesi ve doğruluk analizi. İstanbul Teknik Üniversitesi Fen Bilimleri Enstitüsü, İstanbul, Yüksek Lisans Tezi, 131 s.

Kršák, B., Blišt’an, P., Pauliková, A., Puškárová, P., Kovanič, L., Palková, J., Zelizňaková, V., 2016. Use of low-cost UAV photogrammetry to analyze the accuracy of a digital elevation model in a case study. Measurement, 91, 276-287.

McLeod, T., Samson, C., Labrie, M., Shehata, K., Mah, J., Lai, P., Elder, J.H., 2013. Using video acquired from an unmanned aerial vehicle (UAV) to measure fracture orientation in an open-pit mine. Geomatica, 67(3), 173-180.

Niethammer, U., James, M.R., Rothmund, S., Travelletti, J., Joswig, M., 2012. UAV-based remote sensing of the Super-Sauze landslide: Evaluation and results. Engineering Geology, 128, 2-11.

Niethammer, U., Rothmund, S., Schwaderer, U., Zeman, J., Joswig, M., 2011. Open source image-processing tools for low-cost UAV-based landslide investigations. International Archives of the Photogrammetry, Remote Sensing and Spatial Information Sciences, 38(1)/C22, 57-62.

Peterman, V., 2015. Landslide activity monitoring with the help of unmanned aerial vehicle. The 
International Archives of Photogrammetry, Remote Sensing and Spatial Information Sciences, 40(1/W4), 215-218.

Popescu, G., Iordan, D., Păunescu, V., 2016. The resultant positional accuracy for the orthophotos obtained with unmanned aerial vehicles (UAVs). Agriculture and Agricultural Science Procedia, 10, 458-464.

Rau, J.Y., Jhan, J.P., Lo, C.F., Lin, Y.S., 2011. Landslide mapping using imagery acquired by a fixed-wing UAV. Int. Arch. Photogramm. Remote Sens. Spat. Inf. Sci, 38(1/C22), 195-200.

Rossi, P., Mancini, F., Dubbini, M., Mazzone, F., Capra, A., 2017. Combining nadir and oblique UAV imagery to reconstruct quarry topography: Methodology and feasibility analysis. European Journal of Remote Sensing, 50(1), 211-221.

Seki, M., Tiryakioğlu, İ., Uysal, M., 2017. Farklı veri toplama yöntemleriyle yapılan hacim hesaplarının karşılaştırılması. Geomatik Dergisi, 2(2), 106-111.

Shahbazi, M., Sohn, G., Théau, J., Ménard, P., 2015. UAV-based point cloud generation for open-pit mine modelling. International Archives of the Photogrammetry, Remote Sensing \& Spatial Information Sciences, 40(1/W4), 313-320.

Shi J., Jinling W, Yaming X., 2011. Object-based change detection using georeferenced UAV images. International Archives of the Photogrammetry, Remote Sensing and Spatial Information Sciences, 38, 177-182.
Tong X, Liu X, Chen P, Liu S, Luan K, Li L, Liu S, Liu X, Xie H, Jin Y, Hong Z., 2015. Integration of UAV-based photogrammetry and terrestrial laser scanning for the three-dimensional mapping and monitoring of open-pit mine areas. Remote Sensing, 7(6), 6635-6662.

Udin, W.S., Ahmad, A., 2014. Assessment of photogrammetric mapping accuracy based on variation flying altitude using unmanned aerial vehicle. IOP Conference Series: Earth and Environmental Science, IOP Publishing, 18(1), 012027.

Ulusoy, İ., Şen, E., Tuncer, A., Sönmez, H., Bayhan, H., 2017. 3D multi-view stereo modelling of an open mine pit using a lightweight UAV. Türkiye Jeoloji Bülteni/Geological Bulletin of Turkey, 60(2), 223242.

Yusoff, A.R., Ariff, M.F.M., Idris, K.M., Majid, Z., Chong, A.K., 2017. Camera calibration accuracy at different UAV flying heights. International Archives of Photogrammetry, Remote Sensing and Spatial Information Sciences, 42(2/W3), 595600 .

Url-1 < https://www.pix4d.com/>, erişim tarihi: 2018. 